\title{
Evaluation of REE potential in Portuguese legacy mines
}

\author{
M. Isabel Dias ${ }^{1, *}$, M. Isabel Prudêncio ${ }^{1}, J$. Carlos Waerenborgh ${ }^{1}$, M. Isabel Paiva ${ }^{1}$, Rosa \\ Marques $^{1}$, Bruno J. C. Vieira ${ }^{1}$, Dulce Russo ${ }^{1}$, Daniela Lobarinhas ${ }^{2}$, Edgar Carvalho $^{2}$, and \\ Carlos Rosa $^{3}$ \\ ${ }^{1} \mathrm{C} 2 \mathrm{TN}$. Campus Tecnológico e Nuclear. Instituto Superior Técnico, Universidade de Lisboa. Estrada \\ Nacional 10 (Km 139,7), 2695-066 Bobadela, Loures, Portugal \\ ${ }^{2}$ EDM, R. Sampaio e Pina, 1 - 7. ${ }^{\circ}, 1070-248$, Lisboa, Portugal \\ ${ }^{3}$ Faculdade de Ciências, Universidade de Lisboa, IDL - Instituto Dom Luiz, Ed. C6, Campo Grande, \\ 1749-016 Lisboa, Portugal
}

\begin{abstract}
REE have unique properties that are mostly used to manufacture high tech devices. Most REE have geochemical properties that cause them to be typically dispersed and not often found in concentrated and economically exploitable forms, and difficult to separate. The ENVIREE project aims to develop environmentally friendly and efficient methods for their extraction from secondary sources. REE contents of tailings from four legacy mining sites have been obtained by INAA and analysed by ${ }^{57} \mathrm{Fe}$ Mössbauer spectroscopy. REE concentrations in the tailings of Covas and Cumieira are more dependent on the REE contents of the primary ores and the treatment to extract the target metals than on the nano-sized oxides present. The tailings' size, REE contents and Mössbauer results support the selection of the Covas tailing as the one to be submitted for further steps of REE extraction on the framework of the project.
\end{abstract}

\section{Introduction}

Rare earth elements (REE) are a set of 15 chemical elements in the periodic table, specifically the 15 contiguous lanthanides that have the same outer electron configuration, therefore tending to have similar chemical behaviour. The REE have unique catalytic, metallurgical, nuclear, electrical, magnetic and luminescent properties that are mostly used to manufacture high tech devices (computers, LCD, cell phones, batteries for hybrid vehicles, optical fiber and wind turbines). Most REE are not in fact rare, but because of their geochemical properties, they are typically dispersed and not often found in concentrated and economically exploitable forms, and so difficult to separate. The ENVIREE project, ERA-MIN programme, aims to develop environmentally friendly and efficient methods for extraction of REE from secondary sources. Therefore, partners of that project have made an inventory and characterization of old mines with favourable conditions to contain REE. In this work, the main aim is to study and categorize tailings

*Corresponding author: isadias@ctn.tecnico.ulisboa.pt 
from Portuguese legacy mines and identifying the most suitable materials for REE extraction. An evaluation of the REE exploration potential was done by examining the legacy mine inventory performed by the Direcção Geral de Energia e Geologia in 2012 [1] and in particular the legacy mines of which EDM is responsible for the environmental rehabilitation $[2,3]$. A pre-selection of sites whose deposits show favourable mineralogical paragenesis to the occurrence of REEs was done. For this work, the legacy mines of Covas (tailings volume: $315500 \mathrm{~m}^{3}$ ), Cumieira (tailings volume: $55000 \mathrm{~m}^{3}$ ), Cabração (tailings volume: $<5000 \mathrm{~m}^{3}$ ) and Verdes (tailings volume: $\sim 50000 \mathrm{~m}^{3}$ ) occurring in NW Portugal were selected, corresponding to older exploitation mainly of tungsten-tin minerals and a variety of accessory minerals that include $\mathrm{Nb}-\mathrm{Ta}$ (COLTAN) minerals.

\section{Methods}

The samples were oven dried at $30^{\circ} \mathrm{C}$, and disaggregated and homogenized by spinning of a PVC container with raw sample in a mixer during 4 hours. After this, samples were ground in agate mortar and sieved on a $63 \mu \mathrm{m}$ sieve.

Chemical analyses were done by instrumental neutron activation analyses (INAA) at CTN, IST, determining REE concentrations with very good accuracy and precision (in general $<5 \%$ ). GSD-9 (sediment) and GSS-4 (soil) of the "Institute of Geophysical and Geochemical Prospecting" (IGGE) were used as reference materials [4]. Samples and standards were irradiated together in the core grid of the Portuguese Research Reactor, RPI, (located at CTN, IST) at $1 \mathrm{MW}$ for $1 \mathrm{~min} 30 \mathrm{sec}$ (short irradiation) and $4 \mathrm{~h}$ (longer irradiation). The irradiations were carried out with a mean thermal neutron flux of $3.96 \mathrm{E} 12$ $\mathrm{n} / \mathrm{cm}^{2} / \mathrm{s} ; \phi_{\text {ther }} / \phi_{\text {fast }}=29.8, \phi_{\text {ther }} / \phi_{\text {epi }}=96.8$. More details of the analytical method may be found elsewhere $[5,6]$.

Tailing samples from the mining sites containing the highest REE contents were analysed by ${ }^{57} \mathrm{Fe}$ Mössbauer spectroscopy in order to estimate the Fe oxidation degree and identify Fe-containing phases, mainly nano-sized Fe oxides which, due to their high surface area / volume ratio may strongly adsorb REE as well as transition metals [6]. The spectra were collected between 295 and $4 \mathrm{~K}$ in transmission mode using a conventional constantacceleration spectrometer and a $25 \mathrm{mCi}{ }^{57} \mathrm{Co}$ source in a $\mathrm{Rh}$ matrix. The velocity scale was calibrated using $\alpha$-Fe foil. Isomer shifts, IS, are given relative to this standard at room temperature. The absorbers were obtained by packing the powdered samples $(5 \mathrm{mg}$ of natural $\mathrm{Fe} / \mathrm{cm}^{2}$ ) into a perspex holder. Low-temperature measurements were performed with the sample immersed in liquid $\mathrm{He}$ in a bath cryostat for measurements at $4.1 \mathrm{~K}$ and in He exchange gas for temperatures $>4.1 \mathrm{~K}$. The spectra were fitted to Lorentzian lines using a non-linear least-squares method [7].

\section{Results and Discussion}

The REE data and relevant parameters are listed in Table 1. A rough variation was found for the total REE content ( $\Sigma \mathrm{REE}$ ), ranging between 30 and $70 \mathrm{mg} / \mathrm{kg}$. The comparison within samples of the same mine reveals similar chondrite normalized REE signatures but variable absolute abundances. Based on the results reported here, the latter may be attributed to the differing REE abundances between primary ore and associated alteration phases, and/or is related to varying fabrication processes adopted during production of ore concentrate. This same reason can explain the diverse Ce anomalies found for the same mine. All samples have $\mathrm{Eu}$ negative anomalies that range from 0.38 to 0.92 . The characteristics of chondrite normalized REE patterns of samples have steep light REE distributions, which are generally ascribed to an enrichment of large ion lithophile element 
caused by partial mantling melting of mantle or crustal rocks, and distinctive heavy REE distributions between the mine deposits. For each mine the same REE trends were observed within samples. When comparing the four mines, Cumieira deposit is more enriched in $\mathrm{Tb}$ and $\mathrm{Yb}$, but depleted in $\mathrm{Lu}$. Cabração materials are more depleted in REE with lower $\mathrm{La} / \mathrm{Sm}$ fractionating.

Table 1. REE contents $(\mathrm{mg} / \mathrm{kg})$ and relative parameters of bulk samples for the abandoned mines of Covas, Cumieira, Cabração and Verdes, Portugal.

\begin{tabular}{|c|c|c|c|c|c|c|}
\hline & $\begin{array}{c}\text { PT-Cov } \\
\text { B3 }\end{array}$ & $\begin{array}{c}\text { PT-Cov } \\
\text { B4 }\end{array}$ & $\begin{array}{c}\text { PT-Cum } \\
\text { D1 }\end{array}$ & $\begin{array}{c}\text { PT-Cum } \\
\text { D2 }\end{array}$ & PT-Cab & PT-Vd \\
\hline $\mathrm{La}$ & 15.6 & 9.71 & 13.3 & 16.1 & 4.79 & 9.86 \\
\hline $\mathrm{Ce}$ & 27.1 & 23.1 & 30.5 & 23.6 & 12.9 & 23.4 \\
\hline $\mathrm{Nd}$ & 12.2 & 11.1 & 12.1 & 11.8 & 8.96 & 10.7 \\
\hline $\mathrm{Sm}$ & 2.09 & 1.39 & 1.73 & 2.43 & 1.06 & 1.11 \\
\hline $\mathrm{Eu}$ & 0.47 & 0.30 & 0.52 & 0.45 & 0.27 & 0.36 \\
\hline $\mathrm{Tb}$ & 0.53 & 0.43 & 1.39 & 1.10 & 0.24 & 0.22 \\
\hline $\mathrm{Dy}$ & 3.09 & 3.54 & 1.98 & 1.13 & 1.00 & 1.80 \\
\hline $\mathrm{Yb}$ & 2.17 & 1.31 & 8.04 & 6.13 & 0.96 & 4.24 \\
\hline $\mathrm{Lu}$ & 0.95 & 1.35 & 0.46 & 0.36 & 0.52 & 0.73 \\
\hline$\Sigma \mathrm{REE}$ & 64.3 & 51.9 & 70.0 & 63.1 & 30.7 & 52.4 \\
\hline $\mathrm{Ce} / \mathrm{Ce} *$ & 0.83 & 1.06 & 1.07 & 0.71 & 1.04 & 1.07 \\
\hline $\mathrm{Eu} / \mathrm{Eu} *$ & 0.59 & 0.72 & 0.45 & 0.38 & 0.71 & 0.92 \\
\hline$(\mathrm{La} / \mathrm{Yb})_{\mathrm{N}}$ & 4.86 & 5.00 & 1.12 & 1.77 & 3.37 & 1.57 \\
\hline$(\mathrm{La} / \mathrm{Sm})_{\mathrm{N}}$ & 4.71 & 4.40 & 4.85 & 4.16 & 2.85 & 5.59 \\
\hline
\end{tabular}

$\Sigma$ REE represents the sum of $\mathrm{La}$ to $\mathrm{Lu}$. $(\mathrm{La} / \mathrm{Yb}) \mathrm{N}$ and $(\mathrm{La} / \mathrm{Sm})_{\mathrm{N}}$, where $\mathrm{N}$ refers to a chondritenormalized value. $\mathrm{Eu} / \mathrm{Eu}{ }^{*}$ refers to $\mathrm{Eu}$ anomaly $\left.=\mathbf{E u N} / \sqrt{ }([\boldsymbol{S} \boldsymbol{m} \boldsymbol{N})) .(\boldsymbol{G d N})\right] . \mathrm{Ce} / \mathrm{Ce}{ }^{*}$ refers to $\mathrm{Ce}$ anomaly $=\mathbf{C e N} / \sqrt{ }([\boldsymbol{L a} \boldsymbol{N})) .(\boldsymbol{N} \boldsymbol{d} \boldsymbol{N})]$ (normalization values from $[8,9])$.

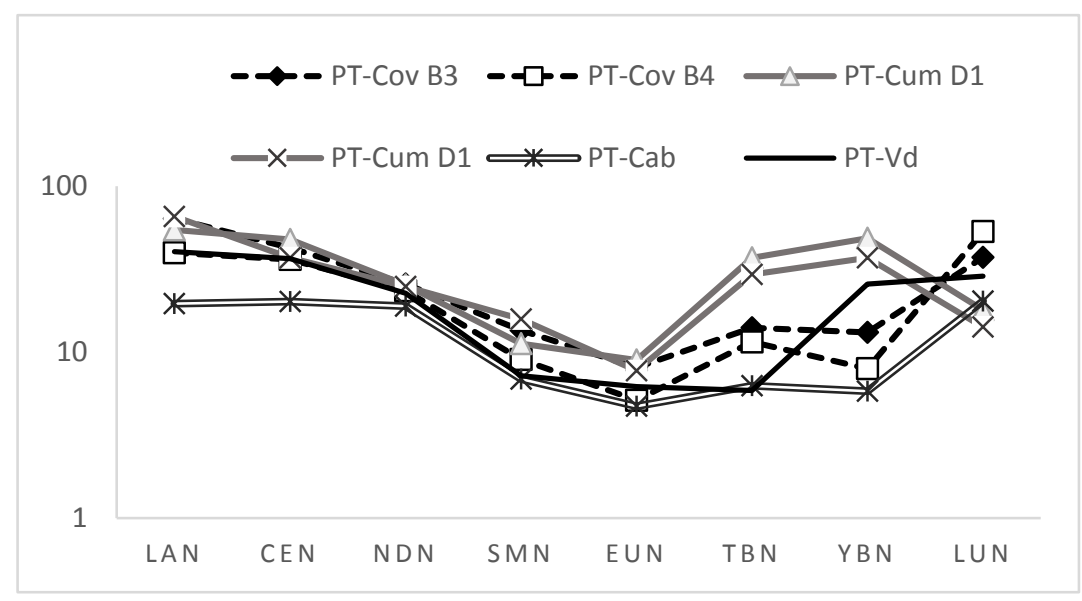

Fig. 1. Chondrite-normalized REE patterns of tailing bodies' samples from Covas, Cumieira, Cabração and Verdes legacy mines (normalization values from [8,9]). 
The doublets and magnetic splittings observed in the Mössbauer spectra at $4 \mathrm{~K}$ (spectra of selected sample in Fig. 2) correspond to contributions from $\mathrm{Fe}^{2+}$ and $\mathrm{Fe}^{3+}$ in several Fe-bearing phases, as explained in detail [10]. Doublets are defined by their IS and quadrupole splitting, QS. In the case of PT-Cum samples the doublets with IS $\sim 0.45 \mathrm{~mm} / \mathrm{s}$, QS $\sim 0.90 \mathrm{~mm} / \mathrm{s}$ and IS $\sim 1.23$ $1.29 \mathrm{~mm} / \mathrm{s}, \mathrm{QS} \sim 2.95 \mathrm{~mm} / \mathrm{s}$ may be assigned to $\mathrm{Fe}^{3+}$ and $\mathrm{Fe}^{2+}$, respectively, in the silicate phases. The magnetic splitting with IS $\sim 1.27 \mathrm{~mm} / \mathrm{s}$ and magnetic hyperfine field $\mathrm{Bhf} \sim 10.2 \mathrm{~T}$ is consistent with pyroxenes containing significant amounts of $\mathrm{Fe}^{2+}$ that become magnetically ordered below $20-25 \mathrm{~K}[10,11]$ Finally the sextet with IS $\sim 0.49 \mathrm{~mm} / \mathrm{s}, \mathrm{Bhf} \sim 50.1 \mathrm{~T}$ and quadrupole shift $\sim-0.24$ $\mathrm{mm} / \mathrm{s}$ is attributed to $\mathrm{Fe}^{3+}$ in goethite which is nano-sized since at room temperature no sextets are observed. In the case of PT-Cov spectra taken at $4 \mathrm{~K}$ in addition to the subspectra observed for PTCum samples a third doublet with IS $\sim 1.42 \mathrm{~mm} / \mathrm{s}$ and QS $3.66 \mathrm{~mm} / \mathrm{s}$ (significantly higher than IS and QS of $\mathrm{Fe}^{2+}$ in silicates) is detected. The very high values of IS and QS are consistent with $\mathrm{Fe}^{2+}$ in hydrated sulphates, possibly melanterite. Furthermore in addition to the goethite sextet a second one with IS $\sim 0.50 \mathrm{~mm} / \mathrm{s}$, Bhf $\sim 51 \mathrm{~T}$ and quadrupole shift $\sim-0.20 \mathrm{~mm} / \mathrm{s}$ is detected. It is assigned to hematite, also nano-sized since the room temperature spectrum of PT-Cum samples show no sextets. The poor crystallinity (small crystal size, unspecific particle shape, structural disorder) and possible $\mathrm{Fe}^{3+}$ isomorphous substitution by impurity cations such as $\mathrm{Al}^{3+}$ explain why these hematite nano-particles did not undergo the Morin transition $[10,11]$. The results deduced from the Mössbauer spectra are summarized in Table 2.

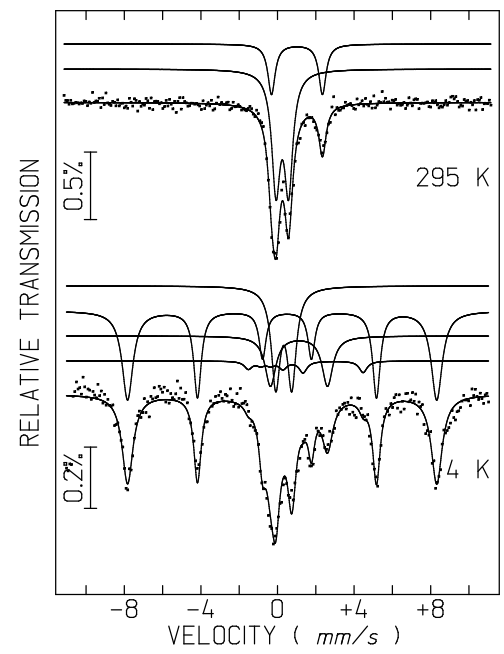

Fig. 2. Mössbauer spectra of PT-Cum-D2 taken at 295 and 4 K. The lines over the experimental points are the sum of two doublets at $295 \mathrm{~K}$, and two doublets plus two magnetic splittings at $4 \mathrm{~K}$ (shown slightly shifted for clarity). They correspond to $\mathrm{Fe}^{2+}$ and $\mathrm{Fe}^{3+}$ in different phases (see text).

Table 2. Fe oxidation degree in the whole samples, fraction of $\mathrm{Fe}^{2+}$ or $\mathrm{Fe}^{3+}$ in different phases.

\begin{tabular}{|c|c|c|c|c|}
\hline Sample & PT-Cov B3 & PT-Cov B4 & PT-Cum D1 & PT-Cum D2 \\
\hline $\mathrm{Fe}^{3+} /$ (total Fe) & $77 \%$ & $93 \%$ & $75 \%$ & $80 \%$ \\
\hline $\mathrm{Fe}^{3+}$ silicate & $20 \%$ & $33 \%$ & $19 \%$ & $24 \%$ \\
\hline $\mathrm{Fe}^{2+}$ silicate & $14 \%$ & $4 \%$ & $25 \%$ & $20 \%$ \\
\hline $\mathrm{Fe}^{2+}$ hydrated sulphate & $7 \%$ & $5 \%$ & - & - \\
\hline $\mathrm{Fe}^{2+}$ arsenopyrite & - & $3 \%$ & - & - \\
\hline $\mathrm{Fe}^{3+}$ nano sized goethite & $57 \%$ & $33 \%$ & $56 \%$ & $56 \%$ \\
\hline $\mathrm{Fe} 3+$ nano sized hematite & - & $19 \%$ & - & - \\
\hline
\end{tabular}


REE concentrations in the tailings of Covas and Cumieira are expected to be more dependent on the REE contents of the primary ores and the treatment to extract the target metals than on the nano-sized oxides present. Comparing the tailings from the same mining sites we observe that PT-Cov B3 has higher REE and nano-sized oxides concentrations than PT-Cov B4 while for PT-Cum D1 and PT-Cum D2 no significant correlation is observed.

\section{Conclusions}

Taking into consideration the foreseen objective of ENVIREE project, the study and categorization of the tailings from Portuguese legacy mines with favourable conditions to contain rare earth elements enabled to identify the most suitable materials for REE extraction. Therefore, the geochemical considerations of Covas, Cumieira, Cabração and Verdes tailings, together with information regarding the tailings' size, supported the selection of the Covas tailings as those to be submitted for further steps of REE extraction on the framework of the project.

We kindly acknowledge funding in the frame of the FCT - ERA-MIN/0004/2014 project, and C2TN FCT project UID/Multi/04349/2013.

\section{References}

1. Direção Geral de Energia e Geologia. Inventários das instalações de resíduos (2012) http://www.dgeg.gov.pt

2. EDM, 2011. The legacy of abandoned mines. The context and the action in Portugal (EDM, DGEG, eds.) ISBN 978-972-95226-2-8

3. EDM, SA - Empresa de Desenvolvimento Mineiro, SA http://edm.pt/

4. K. Govindaraju, Geostand.ards Newslet, 18, 1-15 (1994)

5. E. Martinho, M.A. Gouveia, M.I. Prudêncio, M.F. Reis, J.M.P. Cabral, Appl. Radiat. Isot. 42, 11, 1067-1071 (1991)

6. R. Marques, J.C., Waerenborgh, M.I., Prudêncio, M.I Dias, F. Rocha, E. Ferreira da Silva, Catena 113, 95 (2014)

7. J.C. Waerenborgh, D.P. Rojas, N.P. Vyshatko, A.L. Shaula, V.V. Kharton, I.P. Marozau, E.N. Naumovich, Mater. Lett. 57, 4388 (2003)

8. R.L. Korotev, Geostand. Newslet. 20,217-245 (1996)

9. R.L. Korotev, Meteorit. Planet. Sci. 31, 403-412 (1996)

10. R. Marques, M.I. Prudêncio, J.C. Waerenborgh, F. Rocha, E. Ferreira da Silva, M.I. Dias, J. Madeira, B.J.C. Vieira, J.G. Marques, Catena 147, 522 (2016)

11. E. Murad, Hyperfine Interactions 117, 39 (1998) 